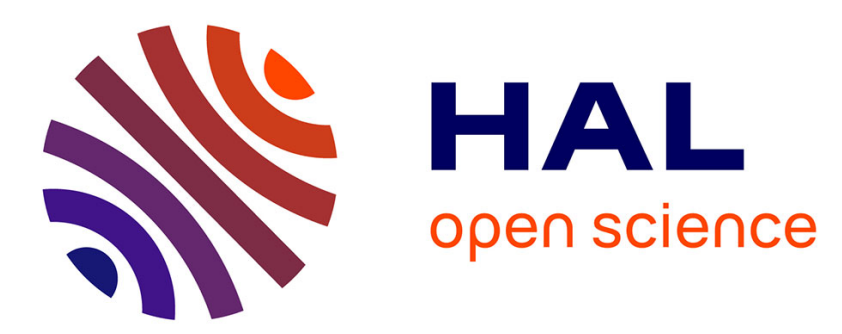

\title{
Impact of smoke-free legislation on children's exposure to second-hand smoke: cotinine data from the Health Survey for England
}

\author{
Martin J. Jarvis, Michelle Sims, Anna B Gilmore, Jennifer Mindell
}

\section{- To cite this version:}

Martin J. Jarvis, Michelle Sims, Anna B Gilmore, Jennifer Mindell. Impact of smoke-free legislation on children's exposure to second-hand smoke: cotinine data from the Health Survey for England. Tobacco Control, 2011, 21 (1), pp.18. 10.1136/tc.2010.041608 . hal-00677619

\section{HAL Id: hal-00677619 \\ https://hal.science/hal-00677619}

Submitted on 9 Mar 2012

HAL is a multi-disciplinary open access archive for the deposit and dissemination of scientific research documents, whether they are published or not. The documents may come from teaching and research institutions in France or abroad, or from public or private research centers.
L'archive ouverte pluridisciplinaire HAL, est destinée au dépôt et à la diffusion de documents scientifiques de niveau recherche, publiés ou non, émanant des établissements d'enseignement et de recherche français ou étrangers, des laboratoires publics ou privés. 
Impact of smoke-free legislation on children's exposure to second-hand smoke: cotinine data from the Health Survey for England

Martin J Jarvis ${ }^{1}$, Michelle Sims ${ }^{2}$, Anna Gilmore ${ }^{2}$, Jenny Mindell ${ }^{1}$

${ }^{1}$ Department of Epidemiology \& Public Health, University College London, 1-19 Torrington Place, London WC1E 6BT, U.K.

${ }^{2}$ Department for Health, University of Bath, Claverton Down, Bath, BA2 7AY, U.K.

The Corresponding Author has the right to grant on behalf of all authors and does grant on behalf of all authors, an exclusive licence on a worldwide basis to the BMJ Publishing Group Ltd and its Licensees to permit this article (if accepted) to be published in Journal Tobacco Control editions and any other BMJPGL products to exploit all subsidiary rights.

Number of words in text: 2587 
What this paper adds

Bans on smoking in public places reduce adults' exposure to second-hand smoke, but effects on children's exposure are less clear, with some suggesting they could increase it, by displacing smoking into the home.

This observational study of cotinine levels in children found no evidence of increased exposure following the implementation of the legislative ban in England in 2007. Adoption of smoke-free homes by smoking parents increased significantly after the ban, suggesting that the ban may have helped reinforce an emerging social norm favouring smoking restrictions. 


\section{Abstract}

Objective: To examine the impact of the ban on smoking in enclosed public places implemented in England in July 2007 on children's exposure to secondhand tobacco smoke.

Design: Repeated cross-sectional surveys of the general population in England.

Setting: The Health Survey for England

Participants: Confirmed non-smoking children aged 4-15 with measured saliva cotinine participating in surveys from 1998 to 2008 , a total of 10,825 children across years.

Main outcome measures: The proportion of children living in homes reported to be smoke free; the proportion of children with undetectable concentrations of cotinine; geometric mean cotinine as an objective indicator of overall exposure.

Results: Significantly more children with smoking parents lived in smoke-free homes in 2008 (48.1\%, $95 \% \mathrm{Cl} 43.0-53.1)$ than in either $2006(35.5 \%, 95 \% \mathrm{Cl} 29.7-41.7)$ or the first 6 months of 2007, immediately before the ban came into effect $(30.5 \%, 95 \% \mathrm{Cl} 19.7-43.9)$. A total of $41.1 \%(95 \% \mathrm{Cl}$ 38.9-43.4) of children had undetectable cotinine in 2008 , up from $34.0 \%(95 \% \mathrm{Cl} 30.8-37.3)$ in 2006 . Geometric mean cotinine in all children combined was $0.21 \mathrm{ng} / \mathrm{ml}(95 \% \mathrm{Cl} .20-.23)$ in 2008 , slightly lower than in 2006, $0.24 \mathrm{ng} / \mathrm{ml}(95 \% \mathrm{Cl} .21-.26)$.

Conclusions: Predictions that the2007 legislative ban on smoking in enclosed public places would adversely affect children's exposure to tobacco smoke were not confirmed. While overall exposure in children has not been greatly affected by the ban, the trend towards the adoption of smoke-free homes by parents who themselves smoke has received fresh impetus. 


\section{Introduction}

Legislation banning smoking in enclosed public places in England came into effect in July 2007. The ban would be expected to have a direct impact on adult exposures through reductions in secondhand smoke in workplaces, pubs, bars and other places of entertainment. Reduced adult exposures have indeed been observed (1), as in other jurisdictions (2-3), along with declines in hospital admissions for myocardial infarction (4). Potential impacts on children are harder to gauge. Children's exposure to other people's smoke takes place largely in the home, and is overwhelmingly determined by parental smoking (5). Any effects on children are therefore likely to be mainly indirect and mediated by changes in parental smoking. During the debates preceding the introduction of legislation it was suggested that a ban could have adverse consequences on children by displacing smoking back into the home. In 2005, giving evidence to the Health Committee of parliament and justifying his preference for a partial ban, the then Secretary of State for Health, Dr John Reid, said: "There will be a displacement if you allowed no smoking in any public place whatsoever. In our case we have got $90 \%$ of pubs and restaurants which will be non-smoking, but there will be some areas. So if you allow none whatsoever there will be a displacement" (6-7). One study of US data has concluded that smoke-free ordinances there have perversely increased children's exposure (8). In Scotland there were reductions in child exposure following introduction of a ban, but the decline only reached statistical significance in children from homes where neither parent smoked (9).

Over the decade or so leading up to the ban there was a substantial decline in children's exposure to tobacco smoke in England (5, 10-11). This was due in part to declines in smoking prevalence in young adults, but also to the increased adoption of smoke-free policies in homes with smoking parents (12). We use data from the Health Survey for England to examine the impact of the 
2007 ban on children's exposure. Specifically, we aim to test whether the ban led to fewer smokefree homes where parents were smokers and whether there was an overall adverse effect on children's exposure.

\section{Methods}

The Health Survey for England (HSE) is an annual survey designed to provide samples representative of households in England in terms of age, gender, geographic location and socioeconomic circumstances. The HSE uses a clustered, stratified multi-stage sample design. In some years a core sample from the general population is supplemented with a boost sample of respondents from particular population groups. Full details of the HSE methodology are available in published reports (13) and online (http://www.ic.nhs.uk/statistics-and-data-collections/health-and-lifestyles-relatedsurveys/health-survey-for-england). All adults and up to two children in participating households are interviewed in the home, followed by a nurse visit to take biological measures (including saliva samples for cotinine) about 1 week later. In 2007 and $200866 \%$ and $64 \%$ respectively of eligible households participated, with $95 \%$ and $93 \%$ of children in co-operating households being interviewed, $68 \%$ and $66 \%$ seeing the nurse, and $59 \%$ and $57 \%$ giving saliva (13-14). These response rates were significantly lower than in 1998, when $74 \%$ of eligible households participated, with $96 \%$ of children in co-operating households being interviewed, $83 \%$ seeing the nurse, and $81 \%$ giving saliva (15).

Parental smoking was ascertained at the initial interview, smokers being identified by a positive response to the screening question "Do you smoke cigarettes at all nowadays?". Children aged 8 and above were asked about smoking through a 6-level smoking experience scale incorporated into 
a self-completion booklet to encourage more accurate self-report. There was no attempt to assess active smoking in children aged under 8.

Information about smoking in the home was gathered for the whole household from a single adult respondent at the initial interview. The household reference person or their partner was asked "Does anyone smoke inside this house/flat on most days?". As previously (12), we define as smokefree those homes where the response to this question was "no", although it is in principle possible that such homes could be mostly rather than completely smoke -free.

\section{Cotinine}

Cotinine is a sensitive and specific quantitative indicator of the extent of uptake of nicotine over the past few days and is accepted as the best available biomarker of exposure to second-hand smoke(16). Specimens for cotinine were collected from children aged under 8 using a straw to dribble saliva through into a sample tube. Older children, like adults, were asked in earlier surveys to keep a dental roll in their mouths until it was saturated and then replace it in the sample tube but since 2007 have collected saliva directly into the tube or using salivettes.

For all years up to and including 2007 an assay using liquid extraction and gas chromatography with nitrogen phosphorous detection (the technique known as GC-NPD) was employed (17) .

Part way through 2008, a new method was introduced using high performance liquid chromatography coupled to tandem mass spectrometry with multiple reaction monitoring (LCMS/MS)(18). To ensure that the LC-MS/MS technique provided results which were comparable with the GC-NPD method, the two techniques were cross-validated. This showed the results from the two methods to be interchangeable. Regular quality controls were run to ensure reliability (13). The limit of detection was $0.1 \mathrm{ng} / \mathrm{ml}$. 
$\underline{\text { Sample }}$

We combined all available data on non-smoking children from 1998 to 2008 inclusive. We excluded data from 1999 and 2004 when only ethnic minorities had a nurse visit, and from 2000, when cotinine specimens were not collected. We defined non-smoking children as those who reported no current smoking and whose cotinine levels were below a cut-point of $12 \mathrm{ng} / \mathrm{ml}$ for active smoking (19). Children aged under 8 were not asked their smoking status and were assumed to be nonsmokers unless their cotinine levels were above $12 \mathrm{ng} / \mathrm{ml}$ ).

\section{$\underline{\text { Statistical analysis }}$}

Data were analysed using the Complex Samples procedures in SPSS 18 to adjust appropriately for the complex survey design involving clustering and stratification. We used supplied weights to compensate for any potential non-response to the nurse visit. These weights are available for the 2003 and later surveys. In the 2007 survey, an additional weight was introduced to further adjust for non-participation in the saliva sample and we used this weight when it became available.

Since the distribution of cotinine concentrations in non-smokers is positively skewed, we subjected the data to logarithmic transformation, first assigning a value of 0.05 , half the limit of detection, to undetectable concentrations. We used three main outcome measures: the proportion of homes that were smoke- free; the proportion of children with undetectable cotinine concentrations (i.e. below the limit of detection of the assay); and geometric mean cotinine concentrations as a quantitative measure of exposure to secondhand tobacco smoke. We compared values in the second half of 2007 and in 2008, after the ban had come into force, with those observed in JanuaryJune 2007 and earlier years. 


\section{Results}

Table 1 shows the numbers of confirmed non-smoking children sampled in each year, and the percentages with smoking or non-smoking parents. There was a significant decline in the percentage of children with smoking parents across years, from $39 \%$ in 1998 to $33 \%$ in 2008 ( $p<.001$ ), but there was no significant change between 2006 and 2008 over the period when the ban came into effect.

The percentage of homes that were smoke-free when parents were non-smokers was over $95 \%$ and showed little change across years. However, there was a marked trend towards increasing adoption of smoke-free homes in households where parents were smokers: from $16 \%$ in 1998 to $48 \%$ in 2008 (Table 2; Figure 1). This trend continued without interruption through the period of implementation of the ban. Significantly more homes with smoking parents were smoke-free in 2008 than in either 2006 or the first 6 months of 2007, immediately before the ban came into effect (p<.001). Overall, the percentage of smoke-free homes increased from $64 \%$ in 1998 to $80 \%$ in 2008 .

Table 3 shows the percentage of children with undetectable cotinine. This was influenced both by whether parents were smokers and whether the home was smoke-free. Fewer than $5 \%$ of children had undetectable cotinine when parents were smokers and there was smoking in the home, but an increasing percentage of children of non-smoking parents living in smoke-free homes had undetectable cotinine, rising from $22 \%$ in 1998 to $59 \%$ in 2008 . Among all children combined a similar trend was observed, and the percentage with undetectable cotinine in 2008 (41\%) was significantly higher than in 2006 (34\%, p<.001), but no different from 2007.

As with undetectable cotinine, geometric mean cotinine in children was strongly influenced both by parents' smoking status and by whether the home was smoke-free (Table 4). Cotinine concentrations in children with smoking parents but whose home was reported to be smoke-free were significantly higher than in children with non-smoking parents $(0.35 \mathrm{ng} / \mathrm{ml}$ versus $0.11 \mathrm{ng} / \mathrm{ml}$ in 
2008), but significantly lower than where parents smoked and there was smoking in the home (1.58 $\mathrm{ng} / \mathrm{ml}$ in 2008), confirming the validity of the household's reported smoke-free status. Among all children combined geometric mean cotinine was on a declining trend across years, going from 0.52 $\mathrm{ng} / \mathrm{ml}$ in 1998 to $0.21 \mathrm{ng} / \mathrm{ml}$ in 2008. The most marked decline occurred between 2005 and 2006 (from $0.38 \mathrm{ng} / \mathrm{ml}$ to $0.24 \mathrm{ng} / \mathrm{ml}$, and there was only a modest further decline in $2008(0.21 \mathrm{ng} / \mathrm{ml}$ ).

\section{Discussion}

Our study, based on both self- report and an objective biomarker of exposure, provides evidence that the 2007 ban on smoking in public places in England has not had adverse consequences for children's exposure to other people's tobacco smoke. Concerns that were expressed before the ban was enacted that adult smoking would be displaced back into the home have not been supported.

There was a marked increase in the 10 years since 1998 in the proportion of children living in a smoke-free home, from $64 \%$ in 1998 to $80 \%$ in 2008 . This was due both to an increase in the percentage of parents who were non-smokers (up from $61 \%$ in 1998 to $67 \%$ in 2008), almost all of whom had smoke-free homes, and to a marked increase in the adoption of smoke-free homes by parents who themselves still smoked. In 2008 close to a half of all such homes were smoke-free, up from only $16 \%$ in 1998. Importantly, this trend to smokers making their home smoke-free did not receive a setback from the implementation of the smoking ban in 2007 , as some had predicted. Rather, the trend to smoke-free homes was if anything accelerated. It would appear that the widespread acceptance and popularity of the ban on smoking in public places may have reinforced the emerging social norm that smoking in enclosed spaces is not acceptable.

Children's exposure to other people's smoke in England has been declining for over two decades (10$11)$, and is now greatly reduced from the late 1980 s. This secular trend, which has been the product of major changes in smoking prevalence and of the gradual adoption of smoking bans in the 
workplace and on public transport, makes it more difficult to detect effects on children's exposure specifically attributable to the implementation of the 2007 legislative ban. Interestingly, the biggest declines in exposure came in the period from 2003 to 2006 during the run-up to the legislative ban, suggesting perhaps that the increased focus on second-hand smoke that accompanied the publicity surrounding the legislation's mooting and discussion in parliament may itself have been an important driver of behaviour change. Measured exposure in 2008, whether in children from nonsmoking homes or in all children combined, showed only a small reduction from that in 2006 just prior to the ban's introduction. The reassuring conclusion from these data is that predictions of displacement of smoking back into the home have received no support, and this hypothesis can now be robustly dismissed. Our period of follow up after the ban's implementation was relatively brief, and it may be that in the longer term there will be further impacts on children's exposure as emerging social norms become more firmly entrenched.

Similar trends to reduced exposure to secondhand smoke over the past two decades have been observed in the USA (20). In 2008, $18 \%$ of children aged 3-11 in the US lived with someone who smoked inside the home(21), close to the $20 \%$ of English children living in a smoking home. In the US, the proportion of children whose cotinine was equal to or below a cotinine detection limit of $0.05 \mathrm{ng} / \mathrm{ml}$ was $46 \%(21)$, again close to the $41 \%$ of English children with cotinine below $01 . \mathrm{ng} / \mathrm{ml}$.

Our study has a number of strengths. The household based sampling frame of the Health Survey for England, with both adults and children being interviewed and measured within the home, enables within-family passive smoking effects to be accurately assessed. The design of the survey permits generalisation to the general population of England. The availability of cotinine measures serves both to validate self-reports and to provide objective quantification of exposure to tobacco smoke. There are also some limitations. In common with other surveys, response rates have declined somewhat in recent years. The relatively small sample sizes when the data for 2007 are divided into 6 month periods, before and after the implementation of the ban, lead to greater imprecision in 
estimates, with wider confidence intervals. The delay of a week or so between the interview and the nurse visit at which saliva samples for cotinine were collected opens up the possibility of a reactive change in smoking habits in the intervening period. However, it is important to note that the question on whether or not there was smoking in the home was asked at the initial interview. Change in household rules subsequent to the interview but before the cotinine sample would only attenuate the relationship between reported household smoking rules and measured cotinine. Furthermore, the report of whether or not there was smoking in the household was gathered from a single adult respondent, who was not necessarily a smoker or the person who smoked in the household. Any bias resulting from delay between interview and sample collection would be present in all survey years, and thus could not explain patterns of exposure change across years. Our operational measure of whether the home was smoke-free specified that there should be no smoking 'most days' rather than always. This means that we may have overestimated the percentage of homes that are completely smoke-free. By the same token, we may have underestimated the extent of the reduction in exposure that children receive from living in a smokefree home. However, since cotinine levels in children with smoking parents but living in a smokefree home were only modestly raised by comparison with children from completely non-smoking homes, it would appear that the extent of any residual smoking in the home was minimal.

There has been considerable success in reducing children's exposure to other people's smoke in England over the past 20 years, reflecting both declines in cigarette smoking prevalence and earlier moves towards restrictions on smoking in public places. It is encouraging that the gains in reduced adult exposure from the legislative ban implemented in 2007 have not come at the expense of increased child exposure. The national strategy for tobacco control adopted by the previous government earlier this year set a target for the year 2020 of increasing to two thirds the proportion of homes where parents smoke but that are entirely smoke free(22). The rapid increase 
in such homes following the ban suggests that achieving this target could be within reach well before 2020.

Acknowledgements This work was supported by funding from the Department of Health's Policy Research Programme to the University of Bath. AG is supported by a Health Foundation Clinician Scientist Fellowship. MS \& AG are members of the UK Centre for Tobacco Control Studies which receives core funding from the British Heart Foundation, Cancer Research UK, Economic and Social Research Council, Medical Research Council, and the National Institute for Health Research under the auspices of the UK Clinical Research Collaboration. The funders played no role in the study design, analysis and interpretation of data, in the writing of the report or the decision to submit the article for publication. The views expressed are those of the authors and not necessarily those of the funders.

The authors declare they have no competing financial interests.

\section{$\underline{\text { References }}$}

1. Sims M, Mindell J, Jarvis M, Gilmore A. Did smokefree legislation in England reduce exposure to secondhand smoke among non-smoking adults?: an analysis of the Health Survey for England. submitted.

2. Haw SJ, Gruer L. Changes in exposure of adult non-smokers to secondhand smoke after implementation of smoke-free legislation in Scotland: national cross sectional survey. BMJ. 2007 Sep 15;335(7619):549. 
3. Pechacek T, Kaufmann R, Trosclair A, Caraballo R, Caudill S. Reduced secondhand smoke exposure after implementation of a comprehensive statewide smoking ban --- New York, June 26, 2003--June 30, 2004. Morbidity and Mortality Weekly Report. 2007;56(28):705-8.

4. Sims M, Maxwell R, Bauld L, Gilmore A. Short term impact of smoke-free legislation in England: retrospective analysis of hospital admissions for myocardial infarction. British Medical Journal. 2010 Jun 8;340:--

5. Royal College of Physicians. Going smoke-free: The medical case for clean air in the home, at work and in public places. London: Royal College of Physicians2005.

6. House of Commons Health Committee. Smoking in Public Places. London: The Stationery Office2005.

7. Arnott D, Dockrell M, Sandford A, Willmore I. Comprehensive smoke-free legislation in England: how advocacy won the day. Tobacco Control. 2007 December 1, 2007;16(6):423-8.

8. Adda J, Cornaglia F. The effect of bans and taxes on passive smoking: Cente for Economic Performance Discussion Paper 950

2009.

9. Akhtar PC, Currie DB, Currie CE, Haw SJ. Changes in child exposure to environmental tobacco smoke (CHETS) study after implementation of smoke-free legislation in Scotland: national cross sectional survey. BMJ. 2007 Sep 15;335(7619):545.

10. Jarvis MJ, Goddard E, Higgins V, Feyerabend C, Bryant A, Cook D. Children's exposure to passive smoking in England since the 1980s: cotinine evidence from population surveys. Br Med J. 2000;321:343-5.

11. Sims M, Tomkins S, Judge K, Taylor G, Jarvis MJ, Gilmore A. Trends in and predictors of second-hand smoke exposure indexed by cotinine in children in England from 1996 to 2006. Addiction. 2010;105(3):543-53.

12. Jarvis MJ, Mindell J, Gilmore A, Feyerabend C, West R. Smoke-free homes in England: prevalence, trends and validation by cotinine in children. Tob Control. 2009 Dec;18(6):491-5.

13. Craig R, Mindell J, Hirani V, editors. Health Survey for England 2008: Volume 2 Methods and Documentation: The NHS Information Centre; 2010.

14. Craig R, Shelton N, editors. Health Survey for England 2007. Vol 2, Methodology and Documentation. Leeds: Health and Social Care Information Centre; 2008.

15. Erens B, Primatesta P, editors. Health Survey for England: Cardiovascular Disease ' 98.

Volume 2: Methodology and Documentation. London: The Stationery Office; 1999.

16. Benowitz NL. Cotinine as a biomarker of environmental tobacco smoke exposure. Epidemiologic Reviews. 1996;18(2):188-204.

17. Feyerabend $\mathrm{C}$, Russell MAH. A rapid gas-liquid chromatographic method for the determination of cotinine and nicotine in biological fluids. Journal of Pharmacy and Pharmacology. 1990;42(6):450-2.

18. Bernert JT, Jacob P, 3rd, Holiday DB, Benowitz NL, Sosnoff CS, Doig MV, et al. Interlaboratory comparability of serum cotinine measurements at smoker and nonsmoker concentration levels: a round-robin study. Nicotine Tob Res. 2009 Dec;11(12):1458-66.

19. Jarvis MJ, Fidler J, Mindell J, Feyerabend C, West R. Assessing smoking status in children, adolescents and adults: cotinine cut-points revisited. Addiction. 2008 Sep;103(9):1553-61.

20. Pirkle JL, Bernert JT, Caudill SP, Sosnoff CS, Pechacek TF. Trends in the exposure of nonsmokers in the U.S. population to secondhand smoke: 1988-2002. Environ Health Perspect. 2006 Jun;114(6):853-8.

21. Centers for Disease Control. Vital Signs: Nonsmokers' exposure to secondhand smoke United States, 1999-2008. Morbidity and Mortality Weekly Report. 2010;59:1141-6.

22. Department of Health. A Smokefree Future: a comprehensive tobacco control strategy for England. London: Department of Health2010. 
Table 1 Number of confirmed non-smoking children aged 4-15 each year, and parental smoking habits.

\begin{tabular}{|l|c|c|c|}
\hline & & \multicolumn{2}{|c|}{ Parental smoking habits } \\
\hline & $\begin{array}{c}\text { Total number of confirmed } \\
\text { non-smoking children aged 4-15 }\end{array}$ & $\begin{array}{c}\text { No parental } \\
\text { smoking }\end{array}$ & $\begin{array}{c}1 \text { or both parents } \\
\text { smoke }\end{array}$ \\
\hline 1998 & 2095 & $60.7(58.0-63.3)$ & $39.3(36.7-42.0)$ \\
\hline 2001 & 1799 & $63.6(60.8-66.3)$ & $36.4(33.7-39.2)$ \\
\hline 2002 & 1064 & $62.2(58.7-65.6)$ & $37.8(34.4-41.3)$ \\
\hline 2003 & 1643 & $62.5(58.8-66.0)$ & $37.5(34.0-41.2)$ \\
\hline 2005 & 706 & $64.3(59.2-69.1)$ & $35.7(30.9-40.8)$ \\
\hline 2006 & 1411 & $66.2(62.6-69.5)$ & $33.8(30.5-37.4)$ \\
\hline 2007 Jan-Jun & 339 & $69.8(63.4-75.6)$ & $29.9(24.2-36.3)$ \\
\hline 2007 July-Dec & 353 & $64.7(57.3-71 . .4)$ & $35.2(28.5-42.6)$ \\
\hline 2008 & 1415 & $66.9(64.3-69.4)$ & $33.1(30.6-35.7)$ \\
\hline
\end{tabular}


Table 2 Percentage of homes reported as smoke- free by parental smoking habits

\begin{tabular}{|c|c|c|c|}
\hline & \multicolumn{2}{|c|}{ Parental smoking habits } & \\
\hline & No parent smokes & $\begin{array}{c}1 \text { or both parents } \\
\text { smoke }\end{array}$ & All children \\
\hline 1998 & $95.5(93.9-96.7)$ & $15.7(12.9-18.9)$ & $64.1(61.5-66.7)$ \\
& 1271 & 824 & 2095 \\
\hline 2001 & $96.5(94.9-97.6)$ & $19.7(16.3-23.6)$ & $68.6(65.8-71.2)$ \\
& 1144 & 654 & 1798 \\
\hline 2002 & $95.5(93.1-97.0)$ & $22.6(18.0-28.8)$ & $68.0(64.5-71.3)$ \\
& 662 & 402 & 1064 \\
\hline 2003 & $95.1(92.7-96.7)$ & $23.2(18.7-28.4)$ & $68.1(64.5-71.5)$ \\
& 1028 & 615 & 1643 \\
\hline 2005 & $97.3(95.0-98.5)$ & $31.2(23.7-39.9)$ & $73.7(68.9-77.9)$ \\
& 459 & 247 & 706 \\
\hline 2006 & $97.6(95.8-98.6)$ & $35.5(29.7-41.7)$ & $76.6(73.2-79.6)$ \\
& 951 & 460 & 1411 \\
\hline 2007 Jan-Jun & $98.3(94.1-99.5)$ & $30.5(19.7-43.9)$ & $78.1(71.8-83.3)$ \\
& 243 & 98 & 341 \\
\hline 2007 July+ & $97.9(93.7-99.3)$ & $40.0(28.6-52.6)$ & $77.2(70.5-82.8)$ \\
& 235 & 118 & 354 \\
\hline 2008 & $96.4(95.1-97.4)$ & $48.1(43.0-53.1)$ & $80.4(78.2-82.4)$ \\
& 972 & 445 & 1417 \\
\hline
\end{tabular}


Table 3 Percentage of confirmed nonsmoking children with undetectable cotinine by parental smoking and whether or not home is smoke-free

\begin{tabular}{|c|c|c|c|c|c|c|c|c|c|}
\hline \multirow[b]{2}{*}{$\begin{array}{l}\text { Parental } \\
\text { smoking }\end{array}$} & \multicolumn{3}{|c|}{ No smoking in home } & \multicolumn{3}{|c|}{ Smoking in home most days } & \multicolumn{3}{|c|}{ All } \\
\hline & $\begin{array}{l}\text { No parental } \\
\text { smoking }\end{array}$ & $\begin{array}{c}1 \text { or both } \\
\text { parents smoke }\end{array}$ & all & $\begin{array}{l}\text { No parental } \\
\text { smoking }\end{array}$ & $\begin{array}{c}1 \text { or both } \\
\text { parents smoke }\end{array}$ & all & $\begin{array}{l}\text { No parental } \\
\text { smoking }\end{array}$ & $\begin{array}{c}1 \text { or both } \\
\text { parents smoke }\end{array}$ & all \\
\hline \multirow[t]{2}{*}{1998} & $22.0(19.6-24.6)$ & $14.0(8.5-22.1)$ & $21.2(19.0-23.7)$ & $8.8(3.8-18.8)$ & $1.3(0.7-2.5)$ & $1.9(1.1-3.1)$ & $21.4(19.1-23.9)$ & $3.3(2.2-4.9)$ & $14.3(12.7-16.0)$ \\
\hline & 1214 & 129 & 1343 & 57 & 695 & 752 & 1271 & 824 & 2095 \\
\hline \multirow[t]{2}{*}{2001} & $19.9(17.5-22.6)$ & $11.6(7.0-18.6)$ & $19.1(16.8-21.6)$ & $2.5(0.3-16.0)$ & $1.5(0.7-3.5)$ & $1.6(0.7-3.5)$ & $19.3(16.9-21.9)$ & $3.5(2.2-5.6)$ & $13.6(11.9-15.5)$ \\
\hline & 1104 & 129 & 1233 & 40 & 525 & 565 & 1144 & 654 & 1798 \\
\hline \multirow{2}{*}{2002} & $25.8(22.1-29.8)$ & $17.6(11.4-26.2)$ & $24.8(21.4-28.5)$ & $6.7(0.9-35.0)$ & $1.6(0.6-4.4)$ & $2.1(0.8-5.1)$ & $24.9(21.3-28.9)$ & $5.2(3.4-8.0)$ & $17.5(14.9-20.4)$ \\
\hline & 632 & 91 & 723 & 30 & 311 & 341 & 662 & 402 & 1064 \\
\hline \multirow[t]{2}{*}{2003} & $21.4(18.7-24.3)$ & $12.0(7.2-19.3)$ & $20.2(17.7-22.9)$ & $4.3(1.3-13.2)$ & $1.4(0.5-3.6)$ & $1.7(0.8-3.6)$ & $20.5(17.9-23.4)$ & $3.9(2.4-6.1)$ & $14.3(12.4-16.4)$ \\
\hline & 982 & 146 & 1128 & 46 & 469 & 515 & 1028 & 615 & 1643 \\
\hline \multirow[t]{2}{*}{2005} & $25.9(21.3-31.2)$ & $9.4(4.5-18.6)$ & 23.4 (19.3-28.2) & $17.5(4.1-51.1)$ & $0.8(0.2-3.0)$ & $1.9(0.7-5.1)$ & $25.7(21.1-30.9)$ & $3.5(1.8-6.7)$ & $17.8(14.5-21.5)$ \\
\hline & 445 & 75 & 520 & 14 & 172 & 186 & 459 & 247 & 706 \\
\hline \multirow[t]{2}{*}{2006} & $47.6(43.5-51.8)$ & $19.4(8.7-26.7)$ & $43.2(39.4-47.1)$ & $16.7(6.2-37.9)$ & $2.9(1.3-6.3)$ & $3.9(2.0-7.2)$ & $46.9(42.8-51.0)$ & $8.8(6.3-12.0)$ & $34.0(30.8-37.3)$ \\
\hline & 931 & 162 & 1093 & 20 & 298 & 318 & 951 & 460 & 1411 \\
\hline 2007 Jan-Jun & $\begin{array}{c}53.7(46.1-61.1) \\
(240)\end{array}$ & $\begin{array}{c}26.5(12.9-46.8) \\
(28)\end{array}$ & $\begin{array}{c}50.5(43.6-57.4) \\
(268)\end{array}$ & $\begin{array}{c}56.4(10.2- \\
93.7) \\
(3)\end{array}$ & $\begin{array}{c}6.2(1.3-24.3) \\
(70)\end{array}$ & $\begin{array}{c}8.9(2.7-25.2) \\
(73)\end{array}$ & $\begin{array}{c}53.7(46.2-61.0) \\
243\end{array}$ & $12.4(6.0-23.9)$ & $\begin{array}{c}41.4(35.3-47.7) \\
341\end{array}$ \\
\hline 2007 Jul-Dec & $\begin{array}{c}59.5(52.2-66.3) \\
(231)\end{array}$ & $\begin{array}{c}16.1(7.5-31.1) \\
(45)\end{array}$ & $\begin{array}{c}51.6(44.8-58.2) \\
(276) \\
\end{array}$ & $\begin{array}{c}0 \\
(5)\end{array}$ & $\begin{array}{c}8.0(3.6-17.0) \\
(73)\end{array}$ & $\begin{array}{c}7.4(3.3-15.3) \\
(78)\end{array}$ & $\begin{array}{c}58.0(50.7-64.9) \\
236 \\
\end{array}$ & $\begin{array}{c}11.2(6.6-18.5) \\
118 \\
\end{array}$ & $\begin{array}{c}41.5(35.6-47.7) \\
254 \\
\end{array}$ \\
\hline 2008 & $\begin{array}{c}58.7(55.9-61.5) \\
(941)\end{array}$ & $\begin{array}{c}16.6(12.5-21.7) \\
(207)\end{array}$ & $\begin{array}{c}50.4(47.8-53.0) \\
(1148)\end{array}$ & $\begin{array}{c}7.2(5.3-9.8) \\
(31)\end{array}$ & $\begin{array}{c}2.6(1.0-6.5) \\
(238)\end{array}$ & $\begin{array}{l}3.2(1.6-6.1) \\
(269)\end{array}$ & $\begin{array}{c}56.9(54.0-59.7) \\
972 \\
\end{array}$ & $\begin{array}{c}9.3(7.1-12.2) \\
445\end{array}$ & $\begin{array}{c}41.1(38.9-43.4) \\
1417 \\
\end{array}$ \\
\hline
\end{tabular}


Table 4 Geometric mean cotinine in confirmed non-smoking children by parental smoking and whether or not home is smoke-free

Nonsmoking children aged 4-15

\begin{tabular}{|c|c|c|c|c|c|c|c|c|c|}
\hline & \multicolumn{3}{|c|}{ No smoking in home } & \multicolumn{3}{|c|}{ Smoking in home most days } & \multicolumn{3}{|c|}{ All } \\
\hline & $\begin{array}{l}\text { No parent } \\
\text { smokes }\end{array}$ & $\begin{array}{c}1 \text { or both } \\
\text { parents smoke }\end{array}$ & All children & $\begin{array}{l}\text { No parent } \\
\text { smokes }\end{array}$ & $\begin{array}{c}\text { 1or both } \\
\text { parents smoke }\end{array}$ & All children & $\begin{array}{l}\text { No parent } \\
\text { smokes }\end{array}$ & $\begin{array}{c}1 \text { both parents } \\
\text { smoke }\end{array}$ & All children \\
\hline & $\begin{array}{l}\text { Mean }(95 \% \\
\mathrm{Cl})\end{array}$ & Mean $(95 \% \mathrm{Cl})$ & Mean $(95 \% \mathrm{Cl})$ & Mean $(95 \% \mathrm{Cl})$ & Mean $(95 \% \mathrm{Cl})$ & Mean $(95 \% \mathrm{Cl})$ & Mean $(95 \% \mathrm{Cl})$ & Mean $(95 \% \mathrm{Cl})$ & Mean $(95 \% \mathrm{Cl})$ \\
\hline 1998 & $.24(.23-.26)$ & $.47(.36-.61)$ & $.26(.24-.28)$ & $.66(.44-.98)$ & $1.98(1.82-2.17)$ & $1.82(1.66-2.00)$ & $.26(.24-.28)$ & $1.58(1.44-1.74)$ & $.52(.48-.57)$ \\
\hline Base & 1214 & 129 & 1343 & 57 & 695 & 752 & 1271 & 824 & 2095 \\
\hline 2001 & $.25(.23-.27)$ & $.45(.35-.56)$ & $.26(.25-.28)$ & $.79(.56-1.10)$ & $1.84(1.65-2.05)$ & $1.73(1.56-1.92)$ & $.26(.24-.28)$ & $1.39(1.24-1.56)$ & $.48(.44-.52)$ \\
\hline Base & 1104 & 129 & 1233 & 40 & 525 & 565 & 1144 & 654 & 1798 \\
\hline 2002 & $.21(.18-.23)$ & $.34(.25-.46)$ & $.22(.20-.24)$ & $.86(.51-.69)$ & $1.95(1.71-2.23)$ & $1.82(1.59-2.08)$ & $.22(.20-.25)$ & $1.32(1.13-1.53)$ & $.43(.39-.48)$ \\
\hline Base & 632 & 91 & 723 & 30 & 311 & 341 & 662 & 402 & 1064 \\
\hline 2003 & $.25(.23-.27)$ & $.41(.33-.50)$ & $.21(.24-.28)$ & $1.25(.78-2.00)$ & $1.71(1.50-1.96)$ & $1.66(1.46-1.90)$ & $.27(.24-.29)$ & $1.23(1.08-1.39)$ & $.47(.43-.52)$ \\
\hline Base & 982 & 146 & 1128 & 46 & 469 & 515 & 1028 & 615 & 1643 \\
\hline 2005 & $.21(.18-.24)$ & $.46(.31-.69)$ & $.24(.21-.27)$ & $.45(.21-.99)$ & $1.60(1.34-1.91)$ & $1.47(1.23-1.76)$ & $.21(.19-.24)$ & $1.09(.89-1.33)$ & $.38(.33-.44)$ \\
\hline Base & 445 & 75 & 520 & 14 & 172 & 186 & 459 & 247 & 706 \\
\hline 2006 & $.12(.11-.13)$ & $.32(.25-.40)$ & $.14(.13-.15)$ & $.58(.30-1.12)$ & $1.39(1.15-1.67)$ & $1.31(1.08-1.57)$ & $.12(.11-.14)$ & $.82(.70-.97)$ & $.24(.21-.26)$ \\
\hline Base & 931 & 162 & 1093 & 20 & 298 & 318 & 951 & 460 & 1411 \\
\hline 2007 Jan-Jun & $.11(.09-.12)$ & $.18(.11-.30)$ & $.11(.10-.13)$ & $.17(.03-.89)$ & $1.75(1.14-2.69)$ & $1.54(.99-2.40)$ & $.11(.09-.12)$ & $.88(.57-1.35)$ & $.20(.16-.25)$ \\
\hline Base & 240 & 28 & 268 & 3 & 70 & 73 & 243 & 98 & 341 \\
\hline 2007 Jul-Dec & $.08(.07-.09)$ & $.43(.25-.74)$ & $.11(.09-.13)$ & $.51(.14-1.85)$ & $1.31(.91-1.89)$ & $1.22(.85-1.77)$ & $.09(.08-.10)$ & $.84(.61-1.15)$ & $.19(.16-.24)$ \\
\hline Base & 231 & 45 & 276 & 5 & 73 & 78 & 236 & 118 & 354 \\
\hline 2008 & $.11(.10-.11)$ & $.35(.30-.41)$ & $.13(.13-.14)$ & $.52(.49-.54)$ & $1.58(1.45-1.73)$ & $1.38(1.27-1.50)$ & $.11(.10-.12)$ & $.77(.67-.87)$ & $.21(.20-.23)$ \\
\hline Base & 941 & 207 & 1148 & 31 & 238 & 269 & 972 & 445 & 1417 \\
\hline
\end{tabular}


Figure 1

Percentage of non-smoking children living in a smoke-free home

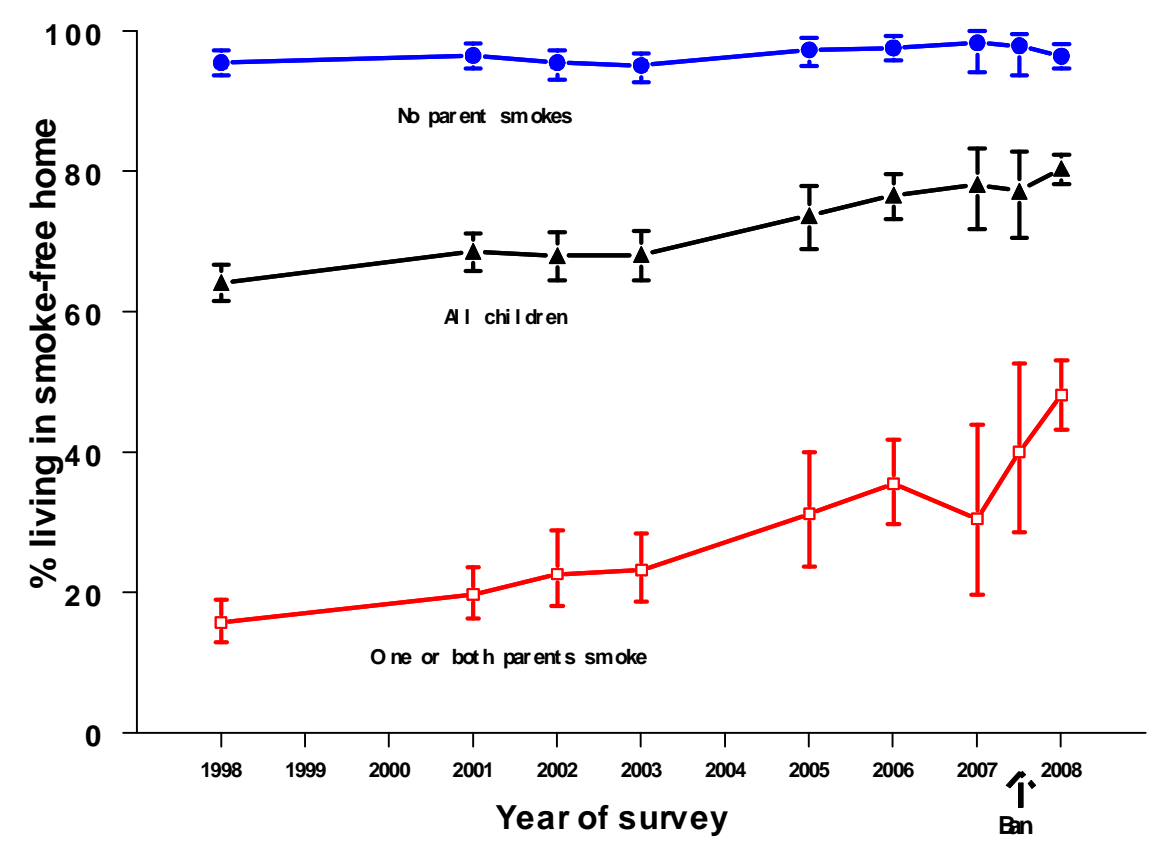


Figure 2

Geometric mean cotinine in non-smoking children by whether or not home is smoke-free

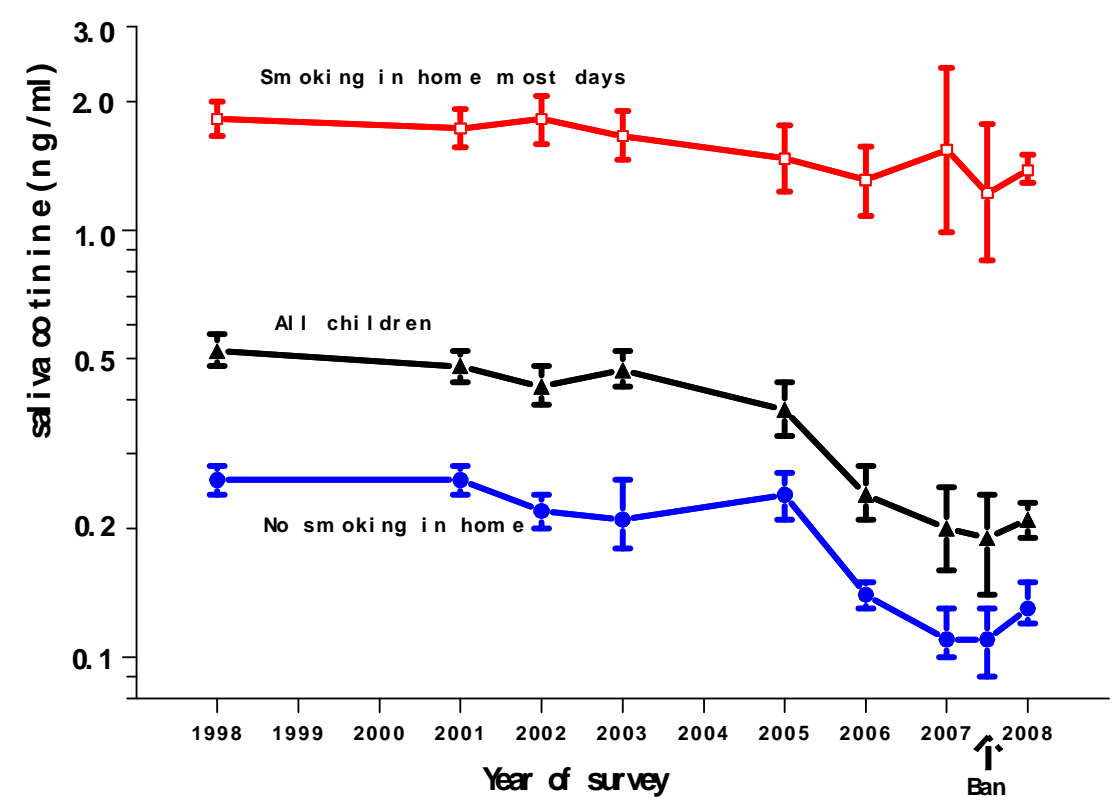




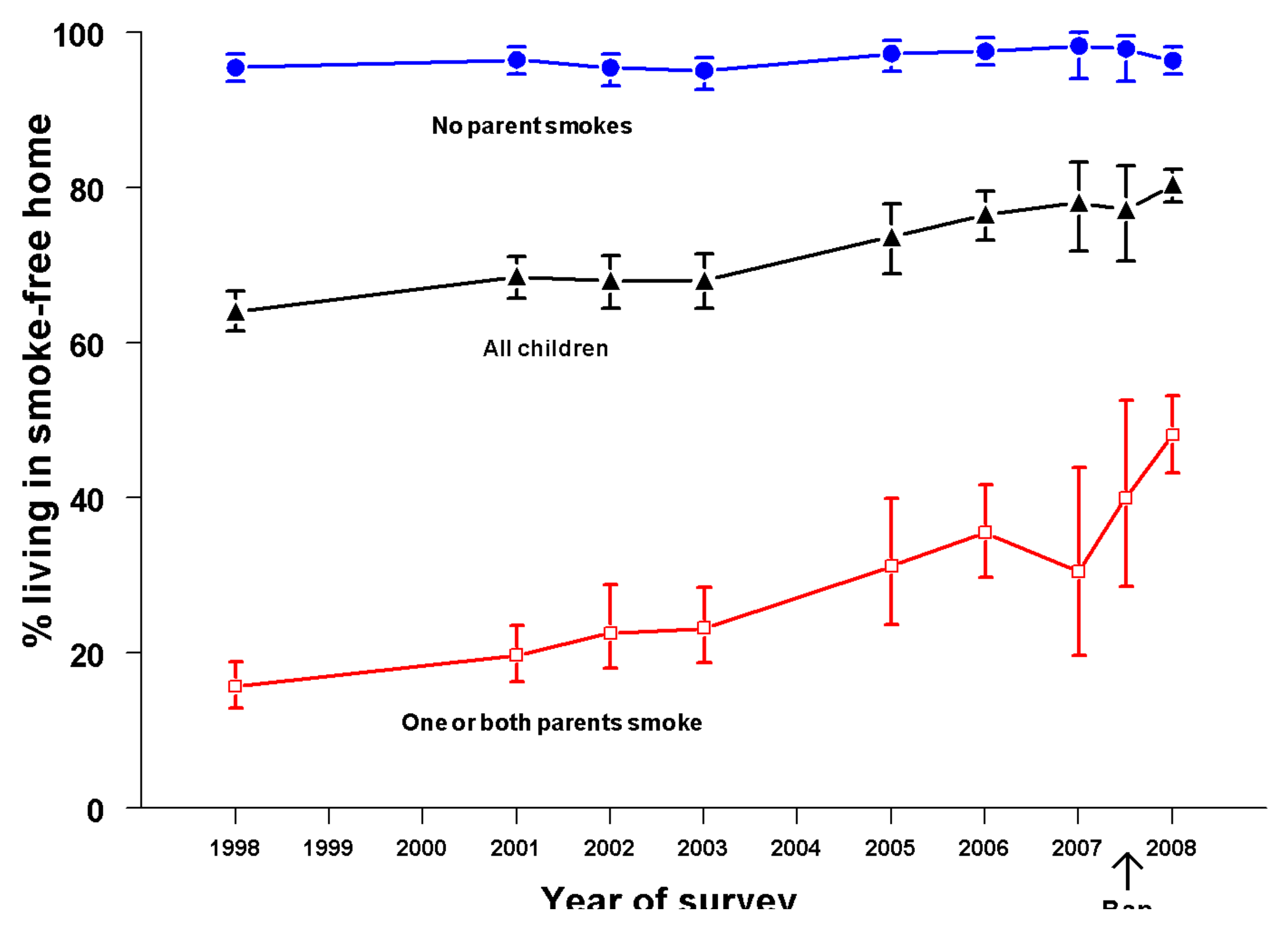



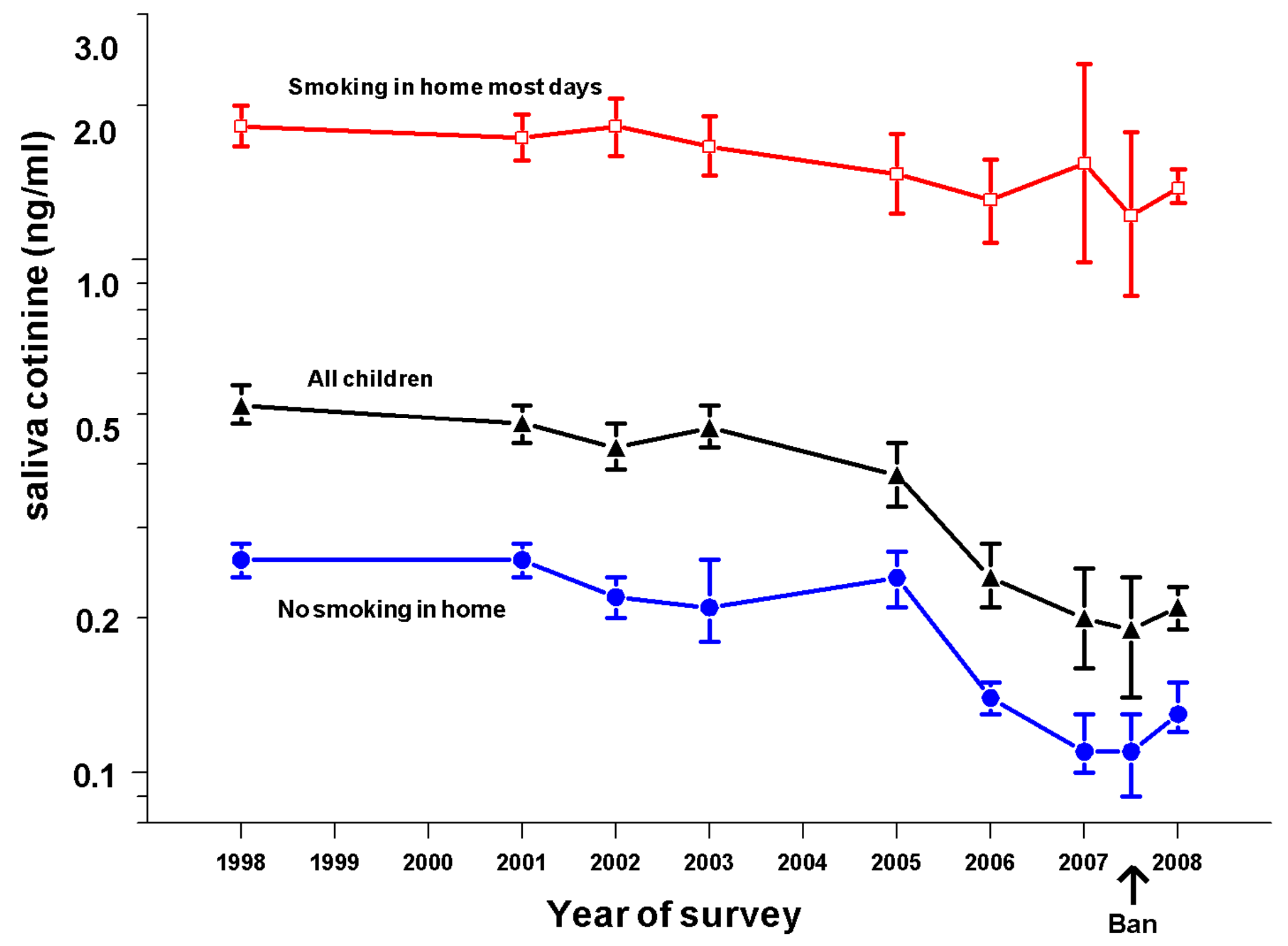